\title{
Identification of Employee Performance Appraisal Methods in Agricultural Organizations
}

\author{
Venclová Katerina, Šalková Andrea, Koláčková Gabriela
}

\begin{abstract}
A formal employee performance appraisal is regarded as one of the tools of human resources performance management. People, their knowledge and skills are currently considered to be the most valuable resource a company has. The article focuses on methods of employee performance appraisal in agricultural organizations in the Czech Republic. The first part of the article deals with the theoretical background of the term "formal appraisal" and employee performance appraisal methods as defined by Czech and foreign specialists. Further, the article describes, based on a questionnaire survey, employee performance appraisal methods that are considered important for the agricultural organizations in the Czech Republic. The aim of the article is to identify the current state of formal employee appraisal in a sample group of agricultural organizations and to test dependencies between selected qualitative characteristics. The outcomes show that the most commonly used methods of employee performance appraisal in agricultural organizations include predefined goal-based performance appraisal, predefined standard outcome-based performance appraisal and appraisal interviews. Agricultural organizations apply these methods in particular due to the fact that their findings are further utilized in other areas of human resource management, such as reward system and personnel planning. In statistical terms, dependency between the method of employee performance appraisal according to predefined goals applied by agricultural organizations and personnel planning (an area of human resources management) has been proven (p-value: 0.032, Phi coefficient: 4.578).
\end{abstract}

Key words: agriculture, organization, employee appraisal, appraisal methods, employee

\section{INTRODUCTION}

At present, people, their knowledge and skills are considered to be the most valuable resource a company has, therefore it is necessary not only to reward and develop them (Hroník, 2006; Koubek, 2007; Banfield \& Kay, 2008; Bělohlávek, 2009; Plamínek, 2010), but also to evaluate them, since employee performance appraisal together with reward system represent an important part of employee performance management (Dessler in Kondrasuk, 2011; Palailogos, Popazekos, Panavotopoulou, 2011; Lussier \& Hendon 2012; Snell \& Bohlander 2012).

Formal employee performance appraisal is an evaluation process through which managers evaluate, compare and provide feedback on employee performance (Kocianová, 2010; Giangrecco, Carugati, Sabastino, Al Tamini, 2012, Murphy \& Cleveland in Spence \& Keeping, 2011) and manage human resources in an organization (Roberts, 2003; De Andrés, García - Lapresta, Gonzáles Pachón, 2010).

Employee performance appraisal is valuable for the organization, the manager as well as for the employee evaluated. Appraisal efficiency is determined by selected appraisal criteria, selected ap- 
praiser/s, selected appraisal methods and the quality of their application (Lukášová, 2010).

Knowledge regarding the specific HRM challenges farms are currently facing, and even their specific HRM practices and strategies, is limited. Identifying and structuring HRM practices and related risk in animal agriculture are important to help frame questions and provide empirical grounding for future in-depth research of agriculture HRM (Bitsch, Kassa, Harsh and Mugera, 2006). Agribusiness managers have little to rely on, when developing personnel policies and procedures for a growing business. Practices developed for large corporations often times do not scale down well to smaller businesses or may not fit the agricultural or agribusiness environment (Bitsch, 2009).

The number of employees as of 31 December 2011 in agricultural, forestry and fishing sector (according to CZ-NACE) amounted to 151,200, which represents 3.1\% of the overall number of employees involved in the national economy (NE) of the Czech Republic. This section ranks 9th (out of 19 sections as defined by CZ-NACE) as far as employment in the NE of the Czech Republic is concerned (Czech Statistical Office [CZSO], 2011).

The need to address the issue of human resources in agriculture resulted from the different position of agriculture to other sectors. The other need was the lack of information on human resource management (performance appraisal as an integral part of human resource management) in agriculture. This fact is supported by a few experts (Bitsch, Kassa, Harsh and Mugera, 2006; Bitsch, 2009).

The aim of this article is therefore the identification of the current state of formal employee appraisal in the sample group of agricultural organizations, based on analysis of survey data and testing of dependencies between selected qualitative characteristics that relate to the issues examined.

The article was produced on the basis of an analysis of primary and secondary sources, in particular research articles focusing on employee performance appraisal. Primary data is derived from a questionnaire survey carried out to explore the use of performance appraisal methods in agricultural organizations in the Czech Republic.

\section{THEORETICAL BACKGROUND}

Performance management can be defined as a systematic process for improving organizational performance by developing the performance of individuals and teams (Armstrong, 2012). Performance management is the system through which organizations set work goals, determine performance standards, assign and evaluate work, provide performance feedback, determine training and development needs and distribute rewards (Briscoe \& Claus, 2008). Performance management is a process involving performance planning, performance managing, performance appraisal, performance rewarding and performance development (Deb, 2009). Performance appraisal can be defined as the formal assessment and rating of individuals by their managers (Armstrong, 2012).

\subsection{Formal employee performance appraisal}

Employee performance appraisal has two forms - formal (systematic) and informal (non-systematic) appraisal. 
Informal appraisal means continuous evaluation of an employee by her/his superior during the work process (Dědina \& Cejthamr, 2005). Formal employee appraisal is a formal organizational process conducted on a systematic basis in order to enable a comparison between the expected individual (group) and real performance (Giangreco et al, 2012). Formal appraisal consists of several phases and selected methods according to appraisal areas (Bělohlávek, 2009).

According to Kondrasuk (2011) formal appraisal may be defined as follows:

- A tool or a mode that evaluates the work performance of an employee.

- An interview in the course of which an employee's work performance is evaluated and the employee is given feedback.

- A system of determining an employee's work prospects/current work performance /evaluated performance/feedback provided to employees through performance appraisal and the possibilities of its future improvement/determining new goals and expectations for another period.

- A part of performance management.

\subsection{Employee performance appraisal methods}

The intention to find an optimal way of employee performance appraisal led to the development of a number of methods. Methods differ in terms of their laboriousness, time demands, costs and usability, e.g. for the purposes of reward of employees subject to the appraisal. A significant criterion for the distinction of methods and their suitability for specific situations is time or whether the method is aimed at the evaluating of work already carried out or the identification of future results. Further, it is possible to classify appraisal methods according to the area of appraisal they cover and the time horizon they focus on.

\subsubsection{Classification of employee performance appraisal methods based on the time factor according the Czech authors}

Three groups of methods may be distinguished according to the time horizon (see Tab. 1): methods focusing on the past that are targeted at past events; methods focusing on the present state that evaluate the current situation and methods focusing on the future that are oriented towards future forecasts (Hroník, 2006). A similar system of method classification is also recognised by Dvořáková (2012) who categorises methods according to the time criterion and distinguishes between methods concentrating on work already performed (on the past) and methods concentrating on the future and identifying the development potential of employees.

Methods focusing on the past have the advantage of dealing with work already done and are therefore relatively measurable. The disadvantage of this method is the impossibility of result alteration. Employee performance appraisal oriented towards the future focuses on future performance (Duda, 2008). 
Tab. 1 - Appraisal methods according to the time perspective as categorised by Czech authors. Source: Own data processed based on information obtained from selected publications (Hroník 2006; Duda 2008; Dvořáková 2012)

\begin{tabular}{|c|c|c|c|}
\hline & $\begin{array}{c}\text { Methods focusing } \\
\text { on the past }\end{array}$ & $\begin{array}{c}\text { Methods focusing } \\
\text { on the present }\end{array}$ & $\begin{array}{c}\text { Methods focusing } \\
\text { on the future }\end{array}$ \\
\hline & \multicolumn{3}{|c|}{ Hroník - X, Dvořáková - Y, Duda - Z } \\
\hline Critical Incident Method & $\mathrm{XYZ}$ & & \\
\hline $\begin{array}{l}\text { Assessment/Development } \\
\text { centre }\end{array}$ & & $\mathrm{X}$ & YZ \\
\hline 360 degree feedback & & $\mathrm{X}$ & $\mathrm{Y}$ \\
\hline Management by Objectives & $\mathrm{Y}$ & & \\
\hline $\begin{array}{l}\text { Predefined Standard Fulfil- } \\
\text { ment based Performance } \\
\text { Appraisal }\end{array}$ & Y & & \\
\hline Checklist & $\mathrm{YZ}$ & & \\
\hline Rating Scales & $\mathrm{YZ}$ & & \\
\hline $\begin{array}{l}\text { Behaviorally Anchored Rating } \\
\text { Scale }\end{array}$ & $\mathrm{Y}$ & & \\
\hline Confidential Report & $\mathrm{Y}$ & & \\
\hline Paired Comparison & $\mathrm{YZ}$ & & \\
\hline Self - Assessment & & & Z \\
\hline
\end{tabular}

2.2.2 Classification of employee performance appraisal methods according to foreign authors

While Czech authors primarily concentrate on the categorisation of methods according to the time criterion, foreign specialists offer more types of method classification. Their classification is as follows:

- traditional and modern methods (Deb, 2006; Khurana, Khurana and Sharma, 2010; Randhawa, 2007),

- objective methods or performance-oriented methods and judgmental methods (Griffin, 2012; Pride, Hughes and Kapoor, 2012),

- scaling methods, narrative methods (Mathis \& Jackson 2011),

- comparative, rating, narrative and behavioural methods (Bogardus, 2007; Schermerhorn, 2011) (Tab. 2).

According to these authors, traditional methods cover methods focusing on performance paired or group comparisons, rating scales and reports, questionnaires, a critical/key incident method, etc. When compared to the classification by Czech authors, there is a link between this classification and the method categorisation according to the time factor, more specifically with methods focusing on the past, i.e. on work already performed. On the other hand, modern methods are partly similar to methods focusing on the future that estimate an employee's development potential. Authors promoting this type of method categorisation (Deb, 2006; Khurana 
et al, 2010; Randhawa, 2007) consider the following methods to be modern ones: Management by Objectives, Assessment Centre, BARS, 360 degree feedback, and human resources accounting. Similarly like Czech authors, foreign authors also differ in their opinions on method classification as well as the grouping of these methods. Thus performance-oriented and judgmental methods also include methods that other authors classify as traditional or modern. As Griffin (2012) states, performance-oriented methods are targeted at the evaluation of current outputs and employee is assessed under standardized conditions, while judgmental methods incorporate rating and ranking techniques (BARS method, rating scales, employee ranking and comparison). Rating methods, according to Mathis and Jackson (2011), include checklists, graphic rating scales and the BARS method. Narrative methods are used in cases requiring written or oral appraisal (they include the free essay (description) and critical/key incident methods (Mathis \& Jackson, 2011). The last group, as defined by foreign authors, consists of comparative, rating, narrative, and behavioural methods. Comparative methods compare work performance of individuals - the most common type is the paired comparison, ranking, forced distribution method and forced choice method. According to Bogardus (2007), the most common appraisal methods are checklists and rating scales. Narrative methods require description of the work performance of an employee by a manager, they include the essay or free narration method, the critical/key incident method and the confidential report. The group of behavioural methods covers the BARS method (Bogardus, 2007).

Tab. 2 - Classification of appraisal method according the foreign authors. Source: Own data processed based on information obtained from selected publications (A - Deb, 2006; C - Randhawa, 2007; G - Bogardus, 2007; F - Mathis \& Jackson, 2011; Schermerhorn, 2011B - Khurana et al, 2010; D - Griffin, 2012; E - Pride et al, 2012)

\begin{tabular}{|c|c|c|c|c|c|c|c|c|}
\hline & \multicolumn{8}{|c|}{ Authors } \\
\hline & A & $\mathrm{B}$ & $\mathrm{C}$ & $\mathrm{D}$ & $\mathrm{E}$ & $\mathrm{F}$ & G & $\mathrm{H}$ \\
\hline \multicolumn{9}{|l|}{ Traditional Methods } \\
\hline Ranking Method & $\mathrm{X}$ & $\mathrm{X}$ & $\mathrm{X}$ & & & & & \\
\hline Paired Comparison & $\mathrm{X}$ & $\mathrm{X}$ & $\mathrm{X}$ & & & & & \\
\hline Rating Scales & $\mathrm{X}$ & $\mathrm{X}$ & $\mathrm{X}$ & & & & & \\
\hline Forced Choice Method & $\mathrm{X}$ & $\mathrm{X}$ & $\mathrm{X}$ & & & & & \\
\hline Forced Distribution Method & $\mathrm{X}$ & $\mathrm{X}$ & $\mathrm{X}$ & & & & & \\
\hline Essay Method & $\mathrm{X}$ & $\mathrm{X}$ & $\mathrm{X}$ & & & & & \\
\hline Group Appraisal Method & $\mathrm{X}$ & & & & & & & \\
\hline Critical Incident Method & $\mathrm{X}$ & $\mathrm{X}$ & $\mathrm{X}$ & & & & & \\
\hline Field Review & $\mathrm{X}$ & $\mathrm{X}$ & $\mathrm{X}$ & & & & & \\
\hline Confidential Reports & $\mathrm{X}$ & $\mathrm{X}$ & $\mathrm{X}$ & & & & & \\
\hline Checklist & & $\mathrm{X}$ & $\mathrm{X}$ & & & & & \\
\hline Person to Person Comparison & & & $\mathrm{X}$ & & & & & \\
\hline
\end{tabular}




\begin{tabular}{|c|c|c|c|c|c|c|c|c|}
\hline Modern Methods & & & & & & & & \\
\hline Management by Objectives & $\mathrm{X}$ & $\mathrm{X}$ & $\mathrm{X}$ & & & & & \\
\hline Assessment Centre & $\mathrm{X}$ & $\mathrm{X}$ & $\mathrm{X}$ & & & & & \\
\hline Human Resources Accounting & $\mathrm{X}$ & $\mathrm{X}$ & $\mathrm{X}$ & & & & & \\
\hline $\begin{array}{l}\text { Behaviourally Anchored Rating } \\
\text { Scale }\end{array}$ & $\mathrm{X}$ & $\mathrm{X}$ & $\mathrm{X}$ & & & & & \\
\hline 360- degree feedback & $\mathrm{X}$ & $\mathrm{X}$ & $\mathrm{X}$ & & & & & \\
\hline Psychological Appraisals & & & $\mathrm{X}$ & & & & & \\
\hline Judgmental Methods & & & & & & & & \\
\hline $\begin{array}{l}\text { Behaviorally Anchored Rating } \\
\text { Scale }\end{array}$ & & & & $\mathrm{X}$ & & & & \\
\hline Rating Scales & & & & $\mathrm{X}$ & $\mathrm{X}$ & & & \\
\hline Ranking & & & & $\mathrm{X}$ & & & & \\
\hline Rating & & & & $\mathrm{X}$ & & & & \\
\hline Scaling Methods & & & & & & & & \\
\hline Checklist & & & & & & $\mathrm{X}$ & & \\
\hline Graphic Rating Scales & & & & & & $\mathrm{X}$ & & \\
\hline $\begin{array}{l}\text { Behaviorally Anchored Rating } \\
\text { Scale }\end{array}$ & & & & & & $\mathrm{X}$ & & \\
\hline Narrative Methods & & & & & & & & \\
\hline Free Essay Method & & & & & & $\mathrm{X}$ & $\mathrm{X}$ & \\
\hline Critical Incident Method & & & & & & $\mathrm{X}$ & $\mathrm{X}$ & \\
\hline Confidential Reports & & & & & & & $\mathrm{X}$ & \\
\hline Comparative Methods & & & & & & & & \\
\hline Paired Comparison & & & & & & & $\mathrm{X}$ & $\mathrm{X}$ \\
\hline Ranking & & & & & & & $\mathrm{X}$ & \\
\hline Forced Distribution Method & & & & & & & $\mathrm{X}$ & $\mathrm{X}$ \\
\hline Forced Choice Method & & & & & & & $\mathrm{X}$ & \\
\hline Rating Methods & & & & & & & & \\
\hline Checklist & & & & & & & $\mathrm{X}$ & \\
\hline Rating Scales & & & & & & & $\mathrm{X}$ & $\mathrm{X}$ \\
\hline $\begin{array}{l}\text { Behaviorally Anchored Rating } \\
\text { Scale }\end{array}$ & & & & & & & & $\mathrm{X}$ \\
\hline Behavioural Methods & & & & & & & & \\
\hline $\begin{array}{l}\text { Behaviorally Anchored Rating } \\
\text { Scale }\end{array}$ & & & & & & & $\mathrm{X}$ & \\
\hline
\end{tabular}




\subsubsection{Description of selected employee performance appraisal methods according to Czech and foreign authors}

Despite opinion differences in the method classification, both Czech and foreign authors have mutually contributed to the development of descriptions of selected methods.

Predefined goals based performance appraisal is a method where an employee concludes an agreement with his superior regarding the main goals of his/her work for a certain period of time; a plan is developed specifying how and when the goals are to be fulfilled and criteria are determined to check the accomplishment of the goals and the progress towards the goal is regularly monitored until the expiration of the period agreed upon (Dvoráková, 2012). The method evaluates the accomplishment of predefined comprehensive and partial goals that are in harmony with the organization's goals. These are determined during discussions between the employee and the superior (Rőmer, 2006).

In the process of appraisal based on a critical incident or using the Critical Incident Method (Duda 2008; Hroník 2006) or the Critical Incident Technique (Wagnerová, 2008; Bogardus, 2007; Durai, 2010), the appraiser is obliged to keep written records on positive and negative actions related to the work of the employee in question (Durai, 2010). The appraiser marks any successful or unsuccessful act of each employee, is able to detect, in the course of the appraisal process, any critical incident and notify the employee there of (Bogardus, 2007).

Rating scales is the most commonly applied method (Dvořáková, 2012). Rating usually means evaluating the performance and behaviour of an employee according to a predefined scale (Hospodářová, 2008). This method is simple, unambiguous and permits fast appraisal of several employees at a time. The appraiser reviews the employee performance and creates scales that contain groups of features (factors) and the scope of expected performance for each of the features (Durai, 2010).

The Behaviourally Anchored Rating Scale (BARS) method appraises behaviours necessary for the successful performance of work. It focuses on the approach to work, adherence to work procedures and usefulness of an employee's performance (Kocianová, 2010). The BARS method measures employee performance in several areas, such as the quantity and quality of work or the fulfilment of tasks. It describes an efficient and non-efficient performance in each area (Sims, 2002).

The 360 degree feedback method or the 360-degree multi-criteria appraisal of performance provides a comprehensive, multi-level overview of employee performance (Hospodářová, 2008). It is a systematic collection of data and feedback on the performance of individuals or groups and the technical measurement of behaviours and competencies of individuals or groups in the process of fulfilment of predefined goals (Ward, 1997). The Ranking is based on the principle of employee ranking according to their relative value for the organization as compared with other employees (Durai, 2010). This method orders all tasks according to their level of significance and each task then becomes more or less important than the previous one (Kumar, 2011). Methods based on employee ranking according to their work performance lie in the comparison of performance of two or more individuals. The most common example is alternate comparison (the appraiser first chooses the best and the worst employee and follows the procedure until all employees are put on the list), paired comparison (the appraiser compares the first employee with the second employee on the employee list choosing a certain criterion, then with the third and so on and determines the better one in each of the pairs) and Forced Distribution (Koubek, 2007). 


\section{ARTICLE OBJECTIVES AND METHODOLOGY}

The main aim of this article is to identify, based on a quantitative survey, the current state of formal employee performance appraisal in agricultural organizations in the Czech Republic. A partial goal of the article is to test dependencies between selected qualitative characteristics relating to employee performance appraisal.

The article has been prepared using the analysis of secondary resources (scientific publications and articles from specialised databases, such as Emerald, ScienceDirect and ProQuest) and primary resources in the form of results of the quantitative survey conducted in a sample group of agricultural organizations in the Czech Republic.

Primary data was obtained by a questionnaire survey which took place from June to September 2012. Questionnaires were sent electronically using the LimeSurvey application. They were distributed among legal entities whose purpose of business is agriculture and that operate in the Czech Republic. 1,698 organizations were addressed and the questionnaire was completed by 332 respondents (by HR managers, managers and owners). In addition, the first question contains a short explanation of formal appraisal system. The questionnaire return rate was $19.6 \% .73 .8 \%$ of these organizations were small businesses (with up to 50 employees), 25.9\% were mediumsized businesses (from 51 to 249 employees) and $0.3 \%$ were large businesses (with more than 250 employees). Czech businesses accounted for $96.1 \%$, while Czech businesses with foreign participation and foreign businesses represented $2.7 \%$ and $1.2 \%$ respectively. In terms of legal form, the most commonly represented companies were limited liability companies (35.8\%), followed by co-operatives $(26.8 \%)$ and joint stock companies $(22.9 \%)$.

Out of these 332 respondents, only 41 organizations (12.3\%) stated that they used formal employee performance appraisal. The sample group of 41 organizations were later tested for null hypotheses using Pearson's Chi Square Test that may be applied to sample groups consisting of more than 40 respondents.

To process data obtained in terms of absolute and relative frequencies the Microsoft Excel 2007 programme was used.

The statistical analysis was conducted by means of the IBM SPSS programme. Null and alternative hypotheses were developed and tested by means of Pearson's Chi Square Test in association tables (more than 20 percent of theoretical frequencies amounted to less than 5 , therefore it was necessary to merge some of the cells) at the selected significance level of $\alpha=0.05$.

Where dependency between the selected qualitative characteristics was proven (i.e. in the event a null hypothesis was rejected in favour of an alternative hypothesis at the selected level of significance of $\alpha=0.05$ ), the level of dependency was tested by means of Cramer's $V$ test.

\section{RESULTS}

Based on the quantitative survey targeted at the formal employee performance appraisal in a sample group of agricultural organizations in the Czech Republic, a statistical evaluation of results was conducted by means of relative and absolute frequencies focused on employee performance appraisal methods applied by agricultural businesses. 
The following part contains survey outcomes focusing on factors determining the application of the above-mentioned appraisal methods in agriculture and their utilisation in other human resources management areas.

In this section could be mention a difference in the using of performance appraisal methods according to the size of the organizations, their legal forms or the presence of foreign owners. But it was not possible test the dependencies, because they do not meet the conditions for statistics testing (more than $25 \%$ of the theoretical frequencies are less than the 5 ).

\subsection{Employee Performance Appraisal Methods Applied by Agricultural Organizations}

The most commonly applied employee performance appraisal methods in the sample group of agricultural organizations in the Czech Republic are as follows (Fig. 1): predefined goals based performance appraisal $(51.2 \%)$, predefined standard fulfilment based performance appraisal (36.6\%), appraisal interview (29.3\%), rating scale (14.6\%), free essay $(12.2 \%)$, ranking $(7.3 \%)$ and appraisal using the 360-degree method (2.4\%) (Venclová, Königová, Fejfar, 2013).

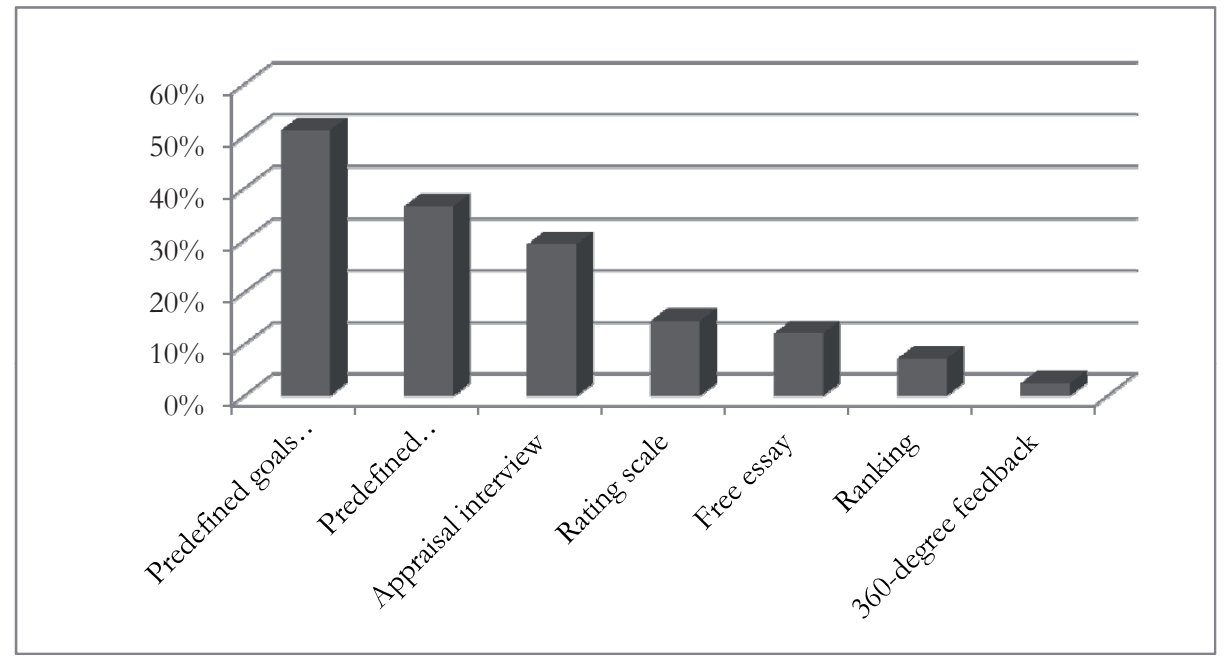

Fig. 1 - Appraisal methods in agricultural organizations in the Czech Republic. Source: Venclová, Königová, Fejfar (2013)

All agricultural organizations that apply the formal system of employee performance appraisal (i.e. 41 businesses) maintain the appraisal results for further use (Fig. 2). They are most frequently used for reward purposes $(92.7 \%)$, personnel planning (19.5\%), education and development $(17.1 \%)$ and career management (7.3\%) (Venclová, Königová, Fejfar, 2013). 


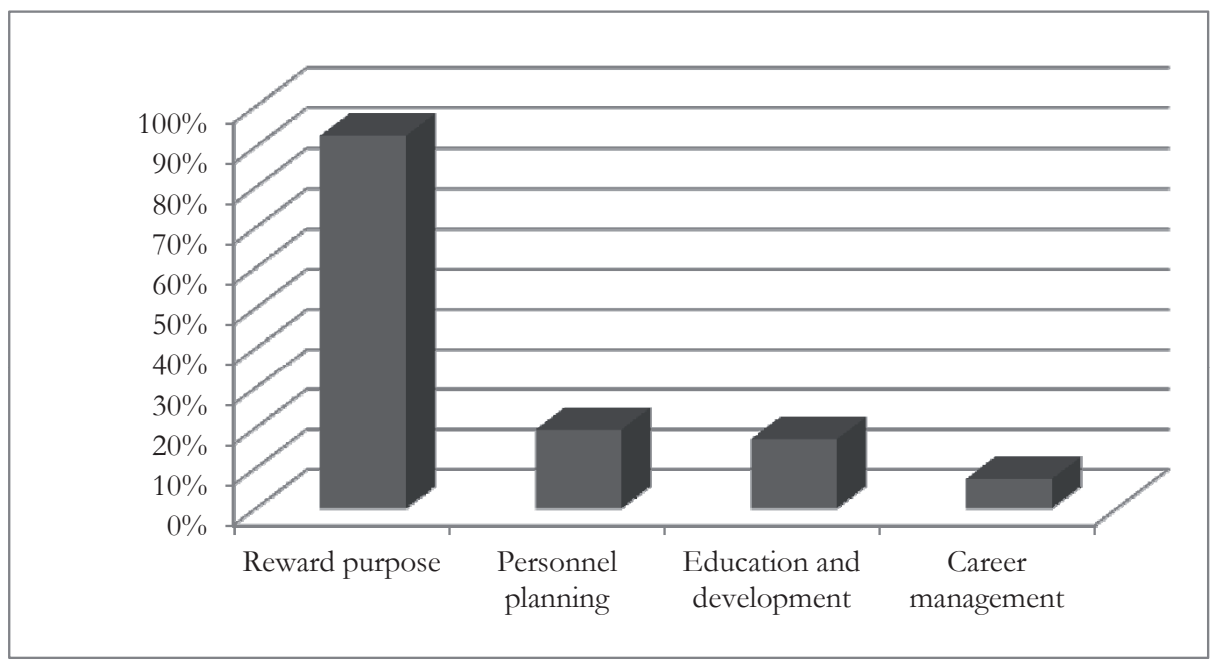

Fig. 2 - Overview of areas of human resources management that use the outcomes of formal employee performance appraisal in agricultural organizations in the Czech Republic. Source: Venclová, Königová, Fejfar (2013)

Based on the above-mentioned data, organizations applying formal employee performance appraisal were selected (i.e. 41 organizations out of the total number of 332) and subsequently tested for null hypotheses no. 1, 2, 3, 4, 5 and 6 on independence between:

- the use of the results of formal employee appraisal in the area of employee reward or

- the use of the results of formal employee appraisal in the area of personnel planning and the method of formal appraisal applied:

- predefined goals based performance appraisal,

- predefined standard fulfilment based performance appraisal,

- appraisal interview.

1. $\mathrm{H}_{0}$ : There is no dependency between the utilization of outcomes of formal appraisal in the area of employee reward and the fact whether predefined goals based performance appraisal is applied as a method of formal employee appraisal.

2. $\mathrm{H}_{0}$ : There is no dependency between the utilization of outcomes of formal appraisal in the area of personnel planning and the fact whether predefined goals based performance appraisal is applied as a method of formal employee appraisal.

3. $\mathrm{H}_{0}$ : There is no dependency between the utilization of outcomes of formal appraisal in the area of employee reward system and the fact whether predefined standard fulfilment based performance appraisal is applied as a method of formal employee appraisal.

4. $\mathrm{H}_{0}$ : There is no dependency between the utilization of outcomes of formal appraisal in the area of personnel planning and the fact whether predefined standard fulfilment based performance appraisal is applied as a method of formal employee appraisal.

5. $\mathrm{H}_{0}$ : There is no dependency between the utilization of outcomes of formal appraisal in the 
area of employee reward system and the fact whether appraisal interview is applied as a method of formal employee appraisal.

6. $\mathrm{H}_{0}$ : There is no dependency between the utilization of outcomes of formal appraisal in the area of personnel planning and the fact whether appraisal interview is applied as a method of formal employee appraisal.

Statistical testing at the level of significance of $\alpha=0.05$ has proven that there is a relationship between the utilization of outcomes of formal appraisal in the area of personnel planning and the fact whether agricultural organizations apply appraisal based on predefined goals as a method of formal employee appraisal. This relationship has proven to be of moderate strength (Tab. 3).

This result confirms Ivorschi (2012), she writes that predefined goals help to control and monitor individuals responsible for implementation of the plan. 'Those involved can control their performance by tracking progress against the targets and take corrective action if necessary.

Studies also show that individuals have higher performance when they are given the opportunity to participate in setting goals to be achieved. It is important for managers to effectively implement suggestions subordinate, but not only enable him feel that he/she listens.'

In comparison with other disciplines researches say, that organization, which is applying method predefined goals, 'could benefit from discussing alternate ways of talking and thinking about its constituent "levels." ' (Wibeck, 2012)

Other null hypotheses at the level of significance of $\alpha=0.05$ may not be rejected and no relationship has been proven between the measured values.

Tab. 3 - Outcomes of testing of hypotheses no. 1 - 6. Source: Own data processed.

\begin{tabular}{|c|c|c|c|c|c|}
\hline $\begin{array}{c}\text { Number of } \\
\text { hypothesis }\end{array}$ & P-value & $\begin{array}{c}\text { Rejection } \\
\text { of H0 }\end{array}$ & $\begin{array}{c}\text { Value of Phi } \\
\text { coefficient }\end{array}$ & $\begin{array}{c}\text { Value of Cram- } \\
\text { er's coefficient }\end{array}$ & $\begin{array}{c}\text { Strength of the } \\
\text { relationship }\end{array}$ \\
\hline 1 & 0,463 & No & 0,538 & - & - \\
\hline 2 & 0,032 & Yes & 4,578 & 0,334 & Moderate \\
\hline 3 & 0,261 & No & 1,262 & - & - \\
\hline 4 & 0,380 & No & 0,771 & - & - \\
\hline 5 & 0,872 & No & 0,026 & - & - \\
\hline 6 & 0,767 & No & 0,087 & - & - \\
\hline
\end{tabular}

\subsection{Opinions of people involved in formal employee performance appraisal and their utilization}

When collecting information within the frame of employee performance appraisal, agricultural organizations most frequently use the opinion of direct superiors $(92.7 \%)$, higher superiors $(39 \%)$, employees evaluated $(24.4 \%)$, customers $(14.6 \%)$, colleagues $(9.8 \%)$ and of a subordinate employee (2.4\%) (Venclová, Königová, Fejfar, 2013).

Out of the above-mentioned data, organizations that apply formal employee appraisal were selected (i.e. 41 organizations out of the total of 332) and subsequently tested for null hypotheses no. $7,8,9,10,11,12,13,14$, and 15 on independence between: 
- the required opinion of a direct superior,

- a higher superior,

- the employee themselves and the fact whether agricultural organizations use the following as a method of formal employee appraisal:

- predefined goals based performance appraisal,

- predefined standard fulfilment based performance appraisal,

- appraisal interview.

7. $\mathrm{H}_{0}$ : There is no dependency between the facts whether an opinion of the direct superior is required in the process of formal employee appraisal and the fact whether predefined goals based performance appraisal is applied as a method of formal employee appraisal.

8. $\mathrm{H}_{0}$ : There is no dependency between the facts whether an opinion of the higher superior is required in the process of formal employee appraisal and the fact whether predefined goals based performance appraisal is applied as a method of formal employee appraisal.

9. $\mathrm{H}_{0}$ : There is no dependency between the facts whether an opinion of the employee himself/herself is required in the process of formal employee appraisal and the fact whether predefined goals based performance appraisal is applied as a method of formal employee appraisal.

10. $\mathrm{H}_{0}$ : There is no dependency between the facts whether an opinion of the direct superior is required in the process of formal employee appraisal and the fact whether predefined standard fulfilment based performance appraisal is applied as a method of formal employee appraisal.

11. $\mathrm{H}_{0}$ : There is no dependency between the facts whether an opinion of the higher superior is required in the process of formal employee appraisal and the fact whether predefined standard fulfilment based performance appraisal is applied as a method of formal employee appraisal.

12. $\mathrm{H}_{0}$ : There is no dependency between the facts whether an opinion of the employee himself/herself is required in the process of formal employee appraisal and the fact whether predefined standard fulfilment based performance appraisal is applied as a method of formal employee appraisal.

13. $\mathrm{H}_{0}$ : There is no dependency between the facts whether an opinion of the direct superior is required in the process of formal employee appraisal and the fact whether appraisal interview is applied as a method of formal employee appraisal.

14. $\mathrm{H}_{0}$ : There is no dependency between the facts whether an opinion of the higher superior is required in the process of formal employee appraisal and the fact whether appraisal interview is applied as a method of formal employee appraisal.

15. $\mathrm{H}_{0}$ : There is no dependency between the facts whether an opinion of the employee himself/herself is required in the process of formal employee appraisal and the fact whether appraisal interview is applied as a method of formal employee appraisal.

Statistical testing at the level of significance of $\alpha=0.05$ has proven that there is a relationship between the facts that an opinion of the employee is required in the process of formal employee appraisal and the fact that appraisal based on standard fulfilment is applied as a method of for- 
mal employee appraisal. This relationship has proven to be of medium strength (Tab. 4).

Wang et al. (2011) found that 'performance evaluation systems have a positive effect on both organizational learning and organizational identification. In addition, organizational learning has a positive effect on organizational identification.'

Other null hypotheses at the level of significance of $\alpha=0.05$ may not be rejected and no relationship has been proven between the measured values.

Tab. 4 - Outcomes of testing of hypotheses no. 7-15. Source: Own data processed.

\begin{tabular}{|c|c|c|c|c|c|}
\hline $\begin{array}{c}\text { Number of } \\
\text { hypothesis }\end{array}$ & P-value & $\begin{array}{c}\text { Rejection } \\
\text { of H0 }\end{array}$ & $\begin{array}{c}\text { Value of Phi } \\
\text { coefficient }\end{array}$ & $\begin{array}{c}\text { Value of Cram- } \\
\text { er's coefficient }\end{array}$ & $\begin{array}{c}\text { Strength of the } \\
\text { relationship }\end{array}$ \\
\hline 7 & 0,414 & No & 0,520 & - & - \\
\hline 8 & 0,444 & No & 0,586 & - & - \\
\hline 9 & 0,414 & No & 0,666 & - & - \\
\hline 10 & 0,834 & No & 0,044 & - & - \\
\hline 11 & 0,070 & No & 3,272 & - & Moderate \\
\hline 12 & 0,021 & Yes & 5,333 & 0,361 & - \\
\hline 13 & 0,950 & No & 0,004 & - & - \\
\hline 14 & 0,154 & No & 2,035 & - & - \\
\hline 15 & 0,153 & No & 2,044 & - & - \\
\hline
\end{tabular}

\section{DISCUSSION}

Formal employee appraisal is an important human resources management tool whose outcomes are utilized in other areas of human resources management, such as:

- reward

- personnel planning

- education and development

- career planning (Manoharan, Muralidharan and Deschmukh, 2012).

The quantitative survey conducted at agricultural organizations in the Czech Republic has confirmed that agricultural organizations apply selected methods of employee performance appraisal in particular due to the fact that they have a relationship to other areas of human resource management.

One function of a performance appraisal system is to provide input for reward decision (Nelson \& Quick, 2008). According to Stephan and Dorfman (1989) outcomes of effective performance appraisal are improvement in the accuracy of employee performance and establishing relationship between performance on tasks and a clear potential for reward. In the survey it has been statistically proven that there is a relationship between the method of appraisal based on predefined goal accomplishment applied by agricultural organizations and personnel planning although the survey outcomes clearly show that the outcomes of formal appraisal are most frequently used in the area of reward $(92.7 \%)$.

The sample group of agricultural organizations apply employee performance appraisal methods, 
such as those based on predefined goals, standard fulfilment, appraisal interviews, rating scale methods, free essay and ranking and the 360-degree feedback. Authors (Hroník, 2006; Wagnerová, 2008; Kocianová, 2010) agree that each method requires a different type of appraiser. Each type of appraiser has its pros and cons (Foot \& Hook, 2002), and therefore it is advisable to apply a multi-source employee appraisal. According to the survey conducted, the application of methods in agricultural organizations ranges across the entire time spectrum. It covers the past (critical incident method, predefined standard fulfilment based performance appraisal), the present (360-degree feedback) as well as the future (predefined goals based performance appraisal) and a method that covers all time horizons and areas of appraisal - i.e. appraisal interviews. Statistical testing has proven a dependency between the request for an opinion of the employee evaluated and the predefined standard fulfilment based performance appraisal despite the fact that a major part of respondents said that it was an opinion of the direct superior that was required most frequently in the process of formal appraisal $(92.7 \%)$.

\section{CONCLUSION}

The quantitative survey conducted shows that only a small number of agricultural organizations apply formal employee performance appraisal.

The outcomes of the survey also reveal that the most commonly applied methods of employee performance appraisal in the sample group (41 companies) are as follows: predefined goals based performance appraisal, predefined standard fulfilment based performance appraisal, appraisal interview, free essay, appraisal based on rating and ranking and the 360-degree feedback. These methods are easily quantifiable and not too time-consuming, with the exception of the 360-degree method which is, however, its advantage is that it provides a comprehensive picture of the employee since the appraisal is usually based on six sources.

According to the survey, agricultural organizations utilize the outcomes of formal employee appraisal in other human resources management areas, in particular in the area of reward $(92.7 \%)$ and personnel planning $(19.5 \%)$. Statistically a dependency has been proven between the predefined goals based performance appraisal applied by agricultural organizations and personnel planning.

In the process of formal employee appraisal, agricultural organizations in the Czech Republic most frequently require an opinion of the direct superior and least frequently an opinion of a subordinate employee. At the level of significance of $\alpha=0.05$, a relationship between the fact that an opinion of the evaluated employee is requested and the fact that the method of appraisal based on standard fulfilment is applied. This relationship has been tested by means of Cramér's $\mathrm{V}$ test and has proven to be of medium strength (0.361).

The 360 degree method is the least frequently applied employee appraisal method in the sample group of agricultural organizations in the Czech Republic and is the only method in the category of methods used that concentrates on the present. Therefore its share should be higher than $2.4 \%$. Agricultural organizations from the sample group should apply more methods focused on a certain type of employees since not all universal methods are able to cover all areas of employee performance appraisal.

\section{Acknowledgement}


This article is a research project of the Czech University of Life Sciences and has been made possible due to the support of the Internal Grant Agency (IGA) of the CULS Prague, Registration Number 20121036 - Employee performance appraisal as a performance management tool.

\section{References}

1. Armstrong, M. (2012). Armstrong's Handbook of Human Resource Management Practice. London: Kogan Page.

2. Banfield, P., \& Kay, R. (2008). Introduction to buman resource management. New York: Oxford University Press.

3. Bělohlávek, F. (2009). Jak vést roz̧hovory s podrízenými pracovniky. Praha: Grada Publishing.

4. Bitsch, V. (2009). Personnel Management Research in Agribusiness. Symposium of the International Food and Agribusiness Management Association. Hungary. Retrieved from: https://www.ifama. org/events/conferences/2009/cmsdocs/1067_paper.pdf

5. Bitsch, V., Kasse, G. A., Harsh, S. B., \& Mugera A. W. (2006). Human Resources Management Risk: Sources and Control Strategies based on Dairy Farmers Focus Groups. Journal of Agriculture and Applied Economics, 38(1), 123-136.

6. Bogardus, M. A. (2007). PHR/SPHR: Professional in Human Resources Certification. Indianapolis: Wiley Publishing.

7. Briscoe, D. B., \& Claus, L. M. (2008). Employee Performance Management: Policies and Practices in Multinational Enterprises. In: Budwah, P. W. \& Denisi, A. (eds.). Performance management system: a global perspective. Abingdon: Routledge.

8. Czech Statistical Office. (2011). Zaměstnanost v NH dle krajü. Retrieved from www.czso. cz/csu/2012edicniplan.nsf/t/EA0034DB14/\$File/31151215.pdf

9. De Andrés, R., García- Lapresta, J. L., \& Gonzáles Pachón J. (2010). Performance appraisal based on distance function methods. European Journal of Operational Research, 207(3), 15991607. http://dx.doi.org/10.1016/j.ejor.2010.06.012

10. Deb, T. (2006). Strategic Approach to Human Resource Management: Concept, Tools \& Application. New Delhi: Atlantic Publishers and Distributors.

11. Deb, T. (2009). Performance Appraisal and Management: concept, antecendents and implications. New Delhi: Excel Book.

12. Dědina, J, \& Cejthamr, V. (2005). Management a organizačni chování. Praha: Grada Publishing.

13. Duda, J. (2008). Řizení lidských żdrojü. Ostrava: Key Publishing.

14. Durai, P. (2010). Human Resources Management. India: Dorling Kindersley.

15. Dvořáková, Z. (2012). Rízení lidskéch zdrojư. Praha: C. H. Beck.

16. Giangreco, A., Carugati, A., Sabastino, A., \& Al Tamini, H. (2012). War outside, ceasefire inside: An analysis of the performance appraisal system of a public hospital in a zone of conflict. Evaluation and Program Planning, 35(1), 161-170. http://dx.doi.org/10.1016/j.evalprog plan.2010.11.004

17. Griffin, W. R. (2012). Fundamentals of Management. USA: South Western Educational Publishing.

18. Hospodářová, I. (2008). Kreativni management v praxi. Praha: Grada Publishing.

19. Hroník, F. (2006). Hodnocení pracovníkư. Praha: Grada Publishing. 
20. Ivorschi, R. (2012). Basis for Promoting Performance and Efficiency Growth of Public Entities, Management by Objectives. Romanian Statistical Review, 60(4), 28-48.

21. Khurana, A., Khurana, P., \& Sharma, H. L. (2010). Human Resource Management. Delhi: Star Offset.

22. Kocianová, R. (2010). Personální činnosti a metody personální práce. Praha: Grada Publishing.

23. Kondrasuk, J. N. (2011). The ideal performance appraisal is a format, not a form. Allied Academies International Conference, 10(1), 61-75.

24. Koubek, J. (2007). Personálni práce v malých a středních firmách. Praha: Grada Publishing.

25. Kumar, R. (2011). Human Resources Ranagement. Strategic Analysis Text and Cases. New Delhi: I. K. International Publishing.

26. Lukášová, R. (2010). Organizačni kultura a její żmèna. Praha: Grada Publishing.

27. Lussier, R. N., \& Henson, J. R. (2012). Human Resource Management: Functions, Applications, Skill Development. Los Angeles: SAGE Publications.

28. Mathis, L. R., \& Jackson, H. J. (2012). Human Resource Management: Essential Perspectives. USA: South-Western Cengage Learning.

29. Monaharan, T. R., Muralidharan, C., \& Deschmukh, S. G. (2012). A composite model for employees' performance appraisal and improvement. European Journal of Training and Development, 36(4), 448-480. http://dx.doi.org/10.1108/03090591211220366

30. Nelson, D. L., \& Quick, J. C. (2008). Understanding Organizational Behavior. USA: Thomson South - Western.

31. Palaiologos, A., Popazekos, P., \& Panavotopoulou, L. (2011). Organizational justice and employee satisfaction in performance appraisal, Journal of European Industrial Training, 35(8), 826-840. http://dx.doi.org/10.1108/03090591111168348

32. Plamínek, J. (2009). Týmová spolupráce a bodnocení lidí. Praha: Grada Publishing.

33. Pride, M. W., Hughes, R. J., \& Kapoor, J. R. (2012). Business. USA Mason: South-Western Publishing.

34. Randhawa, G. (2007). Human Resource Management. New Delhi: Atlantic Publishers and Distributors.

35. Roberts, G. E. (2003). Employee Performance Appraisal System Participation: A Technique that Works. Public Personnel Management, 32(1), 89-97.

36. Rőmer, M. (2006). Management by Objectives. Munich: Grin Publishing.

37. Schermerhorn, R. J. (2011). Organizational Behavior: Experience, Grow, Contribute. Indianapolis. New York: Wiley Publishing.

38. Sims, R. R. (2002). Managing organizational behaviour. Westport: Quorum Books.

39. Snell, S., \& Bohlander, G. (2012). Managing Human Resources. USA, Manson: Cangage Learning.

40. Spence, J. R., \& Keeping, L. M. (2011). Conscious rating distortion in performance appraisal: A review, commentary, and proposed framework for research. Human Resource Management Review, 21(2), 85-95. http://dx.doi.org/10.1016/j.hrmr.2010.09.013

41. Stephan, W., \& Dorfman, P. (1989). Administrative and Developmental Functions Performance Appraisal: Conflict or Synergy? Basic \& Applied Psychology, 10(1), 27-41. http:// dx.doi.org/10.1207/s15324834basp1001_4 
42. Venclová, K., Königová, M., Fejfar, J. (2013). Current State of the Employee Performance Appraisal System in Agricultural Organizations in the Czech Republic. Acta Universitatis Agriculturae et Silviculturae Mendelianae Brunensis, 61(4), 1-7.

43. Wagnerová, I. (2008). Hodnoceni a rízeni výkeonnosti. Praha: Grada Publishing.

44. Wang, H. et al. (2011). University staff performance evaluation systems, organizational learning, and organizational identification in Taiwan. Social Behavior and Personality: an international journal, 39(1), 43-54.

45. Ward, P. (1997). 360 Degree Feedback. Wiltshire: The Cromwell Press.

46. Wibeck, V. (2012). Images of Environmental Management: Competing Metaphors in Focus Group Discussions of Swedish Environmental Quality Objectives. Environmental Management, 49(4), 776-787. http://dx.doi.org/10.1007/s00267-012-9816-7

\section{Contact information}

Ing. Katerina Venclová

Czech University of Life Sciences, Faculty of Economics and Management, Kamýcká 129, 16521 Suchdol, Prague 6, Czech Republic

Email:venclovak@pef.ču.cz.

Ing. Andrea Šalková

Czech University of Life Sciences, Faculty of Economics and Management, Kamýcká 129, 16521 Suchdol, Prague 6, Czech Republic

Email:salkovaa@pef.czu.cz.

\section{Ing. Gabriela Koláčková}

Czech University of Life Sciences, Faculty of Economics and Management, Kamýcká 129, 16521 Suchdol, Prague 6, Cžech Republic

Email:kolackovag@pef.czu.cz.

JEL Classification: M12, Q19 